\title{
Budaya Perusahaan: Penerapan Good Corporare Governance Serta Implikasinya Terhadap Keberlanjutan Kinerja Bank
}

\author{
Agus Supriyatna ${ }^{\mathrm{a}}$, Erwin Yulianto ${ }^{\mathrm{b}}$, Nizar Alam Hamdanic ${ }^{\mathrm{c}}$, Galih Abdul Fatah Maulanic

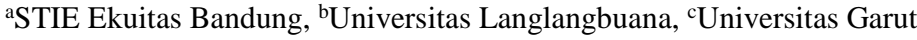 \\ ajoey_bjb@yahoo.com \\ rwinyulianto@yahoo.com \\ Nizar_hamdani@uniga.ac.id \\ galihafm@uniga.ac.id
}

Abstrak-Kinerja merupakan suatu proses manajemen yang dirancang untuk menghubungkan tujuan organisasi dengan tujuan individu sedemikian rupa, sehingga baik tujuan individu maupun tujuan korporasi dapat bertemu. Ukuran dari kinerja perusahaan sangatlah bermacam-macam dan berbeda-beda dari satu industri ke industri lainnya tergantung pada aktivitas pokok perusahaan seperti produksi, keuangan, pemasaran, sumber daya manusia, jasa dan banyak lagi kegiatan usaha lainnya. Pada penelitian ini, jenis industri yang akan diteliti bergerak di bidang jasa perbankan. Kinerja keuangan adalah salah satu tolak ukur dalam menilai suatu bank dan kondisi keuangan yang bagus cenderung menarik perhatian investor. Dalam hubungannya dengan kinerja, laporan keuangan sering dijadikan dasar untuk penilaian kinerja bank karena dapat menunjukkan posisi keuangan dan juga indikator kinerja. Berdasarkan data kinerja dan rasio keuangan perbankan nasional pada tahun 2013 - 2017, dapat dilihat bahwa tren kinerja perbankan cenderung fluktuatif dari tahun ke tahun. Salah satu penyebab turunnya kinerja dan rasio keuangan adalah penerapan Good Corporate Governance (GCG) yang kurang baik. Permasalahan mengenai kinerja perbankan selaras dengan data statistik GCG yang dikeluarkan oleh LPPI pada tahun 2018, dimana rata-rata peringkat GCG untuk Bank Umum Kategori Usaha (BUKU) 1 dan 2 berada di atas standar standar industri perbankan. Selama ini, penerapan GCG dilakukan pada tingkat corporate dan kurang optimalnya implementasi GCG yang dilakukan di tingkat unit bisnis maupun tingkat operasional / fungsional. Pemodelan dari kerangka penelitian dirancang dengan menggunakan model persamaan struktural atau Structural Equation Model (SEM) yang merupakan pendekatan terintegrasi antara Analisis Faktor, Model Struktural dan Path Analysis. Berdasarkan fenomena yang terjadi pada industri perbankan di Indonesia, maka kerangka pemikiran penelitian yang akan ditelaah adalah mengetahui gambaran keberlanjutan kinerja pada industri perbankan di Indonesia yang merupakan dampak dari penerapan GCG yang didukung oleh budaya perusahaan.

Kata Kunci-Budaya Perusahaan, Good Corporate Governance, Keberlanjutan Kinerja Bank, Structural Equation Model

\section{Pendahuluan}

Kinerja merupakan suatu proses manajemen yang dirancang untuk menghubungkan tujuan organisasi dengan tujuan individu sedemikian rupa, sehingga baik tujuan individu maupun tujuan korporasi dapat bertemu [20]. Ukuran dari kinerja perusahaan sangatlah bermacam-macam dan berbeda-beda dari satu industri ke industri lainnya tergantung pada aktivitas pokok perusahaan seperti produksi, keuangan, pemasaran, sumber daya manusia, dan banyak lagi kegiatan lainnya [34].

Jasa perbankan berbeda dengan produk / jasa lainnya karena mengandalkan modal kepercayaan masyarakat yang merupakan sebuah competitive advantage dan berpengaruh terhadap risiko reputasi sebuah bank. Setiap terjadi suatu kasus pada sebuah lembaga perbankan maka akan mempengaruhi persepsi masyarakat akan lembaga perbankan tersebut. Kinerja keuangan adalah salah satu tolak ukur dalam menilai suatu bank dan kondisi keuangan yang bagus cenderung menarik perhatian investor.

Dalam hubungannya dengan kinerja, laporan keuangan sering dijadikan dasar untuk penilaian kinerja bank karena dapat menunjukkan posisi keuangan dan indikator kinerja. Tabel 1 berikut merupakan hasil pengolahan data kinerja dan rasio keuangan perbankan nasional yang diambil langsung dari situs resmi Otoritas Jasa Keuangan. Pada laporan kinerja dan rasio keuangan perbankan nasional di bawah, dapat dilihat bahwa terdapat indikator-indikator dengan tren yang fluktuatif / tidak stabil seperti laba, ROA dan ROE.

TABEL 1. KINERJA DAN RASIO KEUANGAN PERBANKAN NASIONAL TAHUN $2013-2017$

\begin{tabular}{|c|c|c|c|c|c|c|c|c|c|c|}
\hline \multicolumn{2}{|c|}{ Nama Bank } & \multirow{2}{*}{ BCA } & \multirow{2}{*}{\begin{tabular}{|c|} 
Bank \\
Mandiri
\end{tabular}} & \multirow{2}{*}{ BRI } & \multirow{2}{*}{ bank bjb } & \multirow{2}{*}{\begin{tabular}{|c} 
Bank \\
DKI
\end{tabular}} & \multirow{2}{*}{$\begin{array}{c}\text { Bank } \\
\text { Jateng } \\
\end{array}$} & \multirow{2}{*}{\begin{tabular}{|c|} 
Bank \\
Jatim \\
\end{tabular}} & \multirow{2}{*}{$\begin{array}{c}\text { Bank CIMB } \\
\text { Niaga }\end{array}$} & \multirow{2}{*}{$\begin{array}{c}\text { Bank OCBC } \\
\text { NISP }\end{array}$} \\
\hline Tahun & Komponen & & & & & & & & & \\
\hline \multirow{5}{*}{2013} & Laba & \begin{tabular}{|l|l|}
14.364 \\
\end{tabular} & 16.994 & 21.160 & 1.385 & 803 & 717 & 917 & 4.282 & 1.143 \\
\hline & \begin{tabular}{|l} 
Equity \\
\end{tabular} & \begin{tabular}{|l|l|}
62.666 \\
\end{tabular} & 86.867 & 80.868 & 6.669 & \begin{tabular}{|l|}
3.589 \\
\end{tabular} & 2.721 & 5.811 & 28.755 & 14.373 \\
\hline & Aset & \begin{tabular}{|l|l|}
488.508 \\
\end{tabular} & 647.152 & 606.370 & 67.040 & 31.097 & 30.908 & 33.222 & 213.574 & 97.525 \\
\hline & ROA & \begin{tabular}{|l|}
$2,94 \%$ \\
\end{tabular} & $2,63 \%$ & $3,49 \%$ & $2,07 \%$ & $2,58 \%$ & $2,32 \%$ & $2,76 \%$ & $2,01 \%$ & $1,17 \%$ \\
\hline & ROE & $22,92 \%$ & $19,56 \%$ & $26,17 \%$ & $20,77 \%$ & $22,37 \%$ & $26,36 \%$ & $15,78 \%$ & $14,89 \%$ & $7,95 \%$ \\
\hline \multirow{5}{*}{2014} & Laba & \begin{tabular}{|l|l|}
16.027 \\
\end{tabular} & 18.679 & 24.197 & 1.115 & 658 & 774 & 885 & 2.347 & 1.332 \\
\hline & \begin{tabular}{|l|} 
Equity \\
\end{tabular} & \begin{tabular}{|l|}
76.021 \\
\end{tabular} & \begin{tabular}{|l|}
100.344 \\
\end{tabular} & 97.210 & 7.018 & \begin{tabular}{|l|l|}
4.831 \\
\end{tabular} & 3.047 & 6.295 & 31.458 & 15.784 \\
\hline & Aset & \begin{tabular}{|l|l|}
541.911 \\
\end{tabular} & \begin{tabular}{|l|l|}
755.867 \\
\end{tabular} & 778.018 & 70.157 & 37.168 & 35.743 & 42.804 & 227.080 & 103.123 \\
\hline & ROA & \begin{tabular}{|l|}
$2,96 \%$ \\
\end{tabular} & $2,47 \%$ & $3,11 \%$ & $1,59 \%$ & $1,77 \%$ & $2,17 \%$ & $2,07 \%$ & $1,03 \%$ & $1,29 \%$ \\
\hline & ROE & $21,08 \%$ & $18,62 \%$ & $24,89 \%$ & $15,89 \%$ & $13,61 \%$ & $25,42 \%$ & $14,05 \%$ & $7,46 \%$ & $8,44 \%$ \\
\hline \multirow{5}{*}{2015} & Laba & \begin{tabular}{|l|l|}
17.522 \\
\end{tabular} & 20.006 & 25.021 & 1.385 & 228 & 867 & 958 & 428 & 1.501 \\
\hline & \begin{tabular}{|l|l} 
Equity \\
\end{tabular} & 86.770 & 111.412 & 112.218 & 7.699 & 6.079 & 3.727 & 6.063 & 28.698 & 16.411 \\
\hline & Aset & \begin{tabular}{|l|l|}
582.540 \\
\end{tabular} & \begin{tabular}{|l|}
807.787 \\
\end{tabular} & 849.413 & 83.031 & 39.282 & 41.243 & \begin{tabular}{|l|l|}
38.041 \\
\end{tabular} & 233.576 & 120.480 \\
\hline & ROA & \begin{tabular}{|l|}
$3,01 \%$ \\
\end{tabular} & $2,48 \%$ & $2,95 \%$ & $1,67 \%$ & $0,58 \%$ & $2,10 \%$ & $2,52 \%$ & $0,18 \%$ & $1,25 \%$ \\
\hline & ROE & $20,19 \%$ & $17,96 \%$ & $22,30 \%$ & $18,00 \%$ & $3,75 \%$ & $23,28 \%$ & $15,80 \%$ & $1,49 \%$ & $9,15 \%$ \\
\hline \multirow{5}{*}{2016} & \begin{tabular}{|l} 
Laba \\
\end{tabular} & \begin{tabular}{|l|l|}
19.834 \\
\end{tabular} & 13.017 & 25.753 & 1.647 & 657 & 992 & 1.028 & 1.899 & 1.790 \\
\hline & \begin{tabular}{|l} 
Equity \\
\end{tabular} & \begin{tabular}{|l|l|}
109.069 \\
\end{tabular} & \begin{tabular}{|l|l|}
144.183 \\
\end{tabular} & 145.458 & 10.053 & 7.461 & 6.123 & 7.210 & 33.630 & 19.507 \\
\hline & Aset & 662.620 & 918.208 & 964.001 & 97.013 & 41.338 & 51.496 & 43.033 & 236.553 & 138.196 \\
\hline & ROA & \begin{tabular}{|l|}
$2,99 \%$ \\
\end{tabular} & $1,42 \%$ & $2,67 \%$ & $1,70 \%$ & $1,59 \%$ & $1,93 \%$ & $2,39 \%$ & $0,80 \%$ & $1,30 \%$ \\
\hline & ROE & $18,19 \%$ & $9,03 \%$ & $17,71 \%$ & $16,38 \%$ & $8,81 \%$ & $16,21 \%$ & $14,26 \%$ & $5,65 \%$ & $9,18 \%$ \\
\hline \multirow{5}{*}{2017} & \begin{tabular}{|l} 
Laba \\
\end{tabular} & \begin{tabular}{|l|}
22.206 \\
\end{tabular} & 20.011 & 28.469 & 1.607 & 719 & 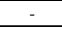 & 1.159 & 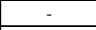 & 2.176 \\
\hline & \begin{tabular}{|l|} 
Equity \\
\end{tabular} & \begin{tabular}{|l|l|} 
\\
\end{tabular} & 159.621 & 165.047 & 10.738 & 8.273 & - & 7.816 & - & 21.784 \\
\hline & Aset & 734.784 & \begin{tabular}{|l|l}
978.328 \\
\end{tabular} & 1.076 .438 & 108.518 & 51.936 & - & 51.519 & - & 153.774 \\
\hline & \begin{tabular}{|l} 
ROA \\
\end{tabular} & $3,02 \%$ & $2,05 \%$ & $2,64 \%$ & $1,48 \%$ & $1,38 \%$ & 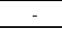 & $2,25 \%$ & - & $1,41 \%$ \\
\hline & ROE & $17,53 \%$ & $12,54 \%$ & $17,25 \%$ & $14,97 \%$ & \begin{tabular}{|l|}
$8,69 \%$ \\
\end{tabular} & 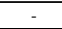 & $14,83 \%$ & 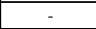 & $9,99 \%$ \\
\hline
\end{tabular}

Menurut Cadbury Committee (1992), salah satu indikator penting yang mempengaruhi ketidakkonsistenan kinerja dipengaruhi oleh beberapa faktor, salah satunya yaitu Good 
Corporate Governance (selanjutnya disebut GCG). GCG mampu mengarahkan dan mengendalikan perusahaan agar tercapai keseimbangan antara kekuatan dan kewenangan perusahaan [7]. Pernyataan ini senadan dengan pernyataan Baird (2000) bahwa salah satu akar penyebab timbulnya krisis moneter di Indonesia adalah buruknya pelaksanaan GCG di lembaga perbankan nasional, baik yang dimiliki pemerintah (BUMN/BUMD), pihak swasta, maupun kepemilikan campuran dengan bank asing [15].

Kegagalan penerapan GCG akan berpengaruh terhadap Tingkat Kesehatan Bank. Tingkat kesehatan bank adalah penilaian kualitatif atas berbagai aspek yang berpengaruh terhadap kondisi atau kinerja suatu bank setelah mempertimbangkan unsur judgement yang didasarkan atas materialitas dan signifikansi dari faktor-faktor penilaian serta pengaruh dari faktor lainnya seperti kondisi industri perbankan dan perekonomian nasional. Kesehatan bank menjadi kepentingan semua pihak (stakeholders) yaitu pemilik modal bank (shareholders), anak perusahaan, manajemen bank, masyarakat sebagai pengguna jasa bank dan pemerintah khususnya Bank Indonesia dan Otoritas Jasa Keuangan sebagai regulator [35]. Tolak ukur yang dilihat oleh pihak manajemen bank adalah bagaimana menjalankan bisnis bank sesuai dengan ketentuan yang berlaku, sehingga dapat terhindar dari permasalahan yang terjadi pada waktu lalu. Kepercayaan dari masyarakat dan stabilitas moneter di Indonesia merupakan faktor yang dipengaruhi dari hal tersebut sehingga apabila kedua hal tersebut bisa dimiliki oleh suatu bank, maka akan menjadi sebuah competitive advantage bagi keberlangsungan usaha perbankan. Bank yang sehat adalah bank yang dapat menjalankan fungsi-fungsinya dengan baik sehingga dapat menjaga kepercayaan masyarakat, dapat menjalankan fungsi intermediasi, dapat membantu kelancaran lalu lintas pembayaran, serta dapat melaksanakan kebijakan moneter [22].

Tren naik turunnya kinerja dan rasio keuangan yang menjadi fenomena perbankan di Indonesia selaras dengan tren GCG yang cenderung naik. Usaha mengembalikan kepercayaan kepada dunia perbankan Indonesia melalui restrukturisasi dan rekapitalisasi, mempunyai dampak jangka panjang apabila disertai tiga tindakan penting, yaitu ketaatan terhadap prinsip kehati-hatian, pelaksanaan GCG, dan pengawasan yang efektif dari otorisasi pengawasan bank [33].

Kajian tersebut didukung oleh fenomenan menarik berdasarkan penelitian yang dilakukan oleh Lembaga Pengembangan Perbankan Indonesia (LPPI) pada periode 2007 sampai dengan 2017. Nilai rata-rata GCG pada Bank Umum Kegiatan Usaha (BUKU) dengan kategori 3 dan 4 berada di atas standar industri, sebaliknya, perbankan dengan kategori BUKU 1 dan BUKU 2 berada di bawah standar industri, sebagaimana Tabel 2 sebagai berikut [12].

TABEL 2. RATA-RATA NILAI GCG BERDASARKAN BUKU 1, 2, 3 DAN 4 PADA PERIODE 2007 - 2017

\begin{tabular}{|c|c|c|c|c|}
\hline No & BUKU & Rata-Rata GCG & Max & Min \\
\hline 1 & BUKU 1 & 2,23 & 2,09 & 2,45 \\
\hline 2 & BUKU 2 & 2,10 & 1,86 & 2,30 \\
\hline 3 & BUKU 3 & 1,85 & 1.68 & 2,11 \\
\hline 4 & BUKU 4 & 1,25 & 1,00 & 1,40 \\
\hline 5 & Industri & 2,05 & 1,84 & 2,21 \\
\hline \multicolumn{4}{|c|}{ Sumber : Lembaga Pengembangan Perbankan Indonesia [12] }
\end{tabular}

Rata-rata nilai GCG berdasarkan BUKU 1, 2, 3, dan 4 didukung oleh tren rata-rata GCG Perbankan dalam negeri yang telah dipublikasi oleh Bisnis Indonesia (2018) sebagaimana Tabel 3 berikut.

TABEL 3. TREn RATA-RATA GCG PERBANKAN DALAM NEGERI PADA PERIODE 2007 - 2017

\begin{tabular}{|c|c|c|c|c|c|c|c|c|c|c|c|}
\hline BUKU & $\mathbf{2 0 0 7}$ & $\mathbf{2 0 0 8}$ & $\mathbf{2 0 0 9}$ & $\mathbf{2 0 1 0}$ & $\mathbf{2 0 1 1}$ & $\mathbf{2 0 1 2}$ & $\mathbf{2 0 1 3}$ & $\mathbf{2 0 1 4}$ & $\mathbf{2 0 1 5}$ & $\mathbf{2 0 1 6}$ & $\mathbf{2 0 1 7}$ \\
\hline I & 2.21 & 2.18 & 2.32 & 2.18 & 2.21 & 2.21 & 2.14 & 2.32 & 2.39 & 2.14 & 2.23 \\
\hline II & 2.19 & 2.08 & 2.00 & 1.90 & 2.09 & 2.13 & 2.08 & 2.10 & 2.21 & 2.21 & 2.10 \\
\hline III & 1.79 & 1.79 & 1.79 & 1.68 & 1.74 & 1.74 & 2.05 & 1.95 & 1.95 & 2.05 & 1.85 \\
\hline IV & 1.20 & 1.20 & 1.00 & 1.00 & 1.00 & 1.20 & 1.20 & 1.40 & 1.40 & 1.60 & 1.25 \\
\hline Industri Perbankan & 2.07 & 2.01 & 2.00 & 1.89 & 2.01 & 2.03 & 2.05 & 2.10 & 2.17 & 2.13 & 2.05 \\
\hline
\end{tabular}

Isu terkait kinerja perbankan dalam lima tahun terakhir yang fluktuatif (tidak stabil) ternyata menyeluruh baik bank pemerintah dan swasta dengan skala nasional, bank nasional campuran, maupun bank pembangunan daerah. Demikian pula dengan tren penilaian self assessment GCG yang tidak konsisten dan cenderung naik (kurang baik).

Penilaian kinerja suatu entitas bisnis dari perbankan saat ini tidak hanya diukur dari aspek keuangan. Tanggung jawab keuangan yang ditampakkan dengan ukuran moneter, akuntansi maupun rasio-rasio tertentu juga harus dilengkapi dengan kinerja non-keuangan seperti penerapan GCG, pelaksanaan operasional internal, sumber daya manusia, dan budaya perusahaan yang mamadai [5]. Konsep GCG yang telah dipaparkan oleh banyak penelitian kebanyakan hanya membahas sisi strategis. Fokus penelitian manajemen strategik mengalami pergeseran dari perencanaan strategi kepada implementasi strategi. Diskusi mengenai implementasi strategi semakin populer dalam satu dasawarsa terakhir sejalan meluasnya kesadaran bahwa implementasi strategi jauh lebih penting daripada formulasi strategi [16].

Selama ini, penelitian mengenai penerapan GCG dilakukan pada tingkat corporate strategy dan belum menyentuh level strategi implementasi GCG yang dilakukan di unit bisnis. Fokus penelitian ini adalah adalah strategi penerapan GCG melalui penguatan budaya perusahaan di unit bisnis, operasional dan fungsional dalam menciptakan keberlanjutan kinerja perbankan nasional. Hasil penelitian yang diharapkan lebih kepada bottom up strategy yaitu operational strategy dan business strategy yaitu fokus pada evaluasi pelaksanaan kegiatan usaha bank sesuai kebijakan, SOP, pedoman, manual produk, dan juknis yang berlaku terhadap kondisi dan situasi yang terjadi di lapangan dengan prinsip kehati-hatian dan kepatuhan terhadap ketentuan internal yang berlaku [36].

\section{KAJIAN PUSTAKA}

\section{A. Konsep Implementasi Strategi Dalam Menciptakan Keberlanjutan Kinerja Bank}

Dalam bukunya, Wheelen dan Hunger (2018) mengatakan bahwa manajemen strategis adalah "set of managerial decisions and actions that determines the long-rum performance of a firm", yang berarti seperangkat kumpulan dari keputusan-keputusan dan tindakan yang menentukan kinerja jangka panjang dari sebuah perusahaan. Manfaat manajemen strategis yang bisa diperoleh antara lain mampu menetapkan visi dan misi secara lebih jelas, fokus yang lebih tajam atas faktor penting secara strategis, meningkatkan pemahaman mengenai perubahan lingkungan yang sangat cepat. Adapun model manajemen strategi menurut Wheelen dan Hunger (2018), dapat dilihat pada Gambar 1 sebagai berikut : 


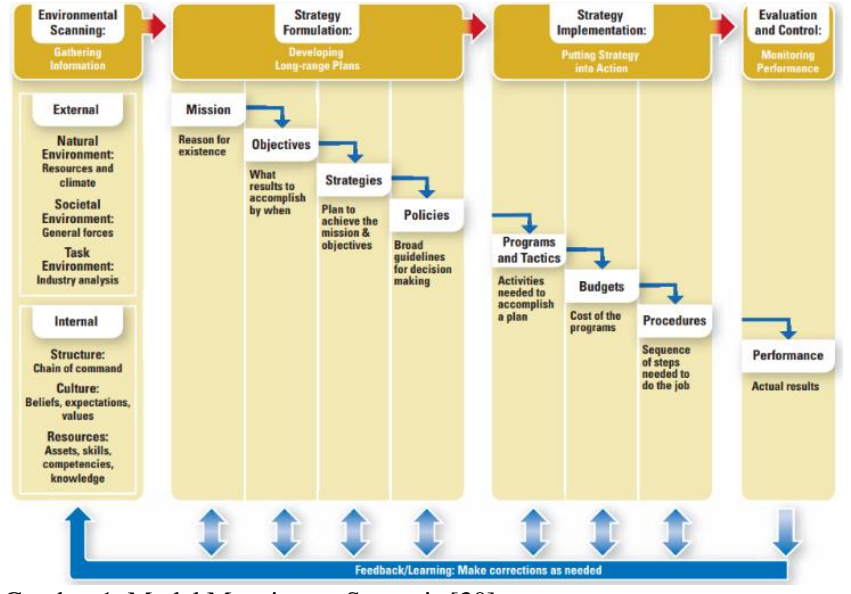

Gambar 1. Model Manajemen Strategis [30]

Rekomendasi atas manajemen strategis harus memiliki pendekatan implementasi dalam bentuk rekayasa ulang, yang merupakan suatu pendekatan baru dalam implementasi strategi dengan meningkatkan kemampuan operasi organisasi. Tidak masalah apapun pilihan strategi perusahaan, yang jauh lebih penting adalah efektivitas implementasi strategi sebagai faktor yang lebih menentukan. Kesenjangan praktis muncul akibat pemahaman peningkatan kualitas implementasi strategi belum dikuasai dengan baik oleh praktisi dan manajemen perusahaan [15]. Pendekatan selanjutnya adalah mendesain pekerjaan dengan cara melakukan restrukturisasi berbagai aktivitas di lembaga perbankan dengan pegawai-pegawai yang ada sehingga menghasilkan desain organisasi yang memadai [30].

Implementasi merupakan tahap yang sangat menentukan dalam proses kebijakan karena tanpa implementasi yang efektif maka keputusan pembuat kebijakan tidak akan berhasil dilaksanakan. Ripley dan Franklin memperkenalkan pendekatan "kepatuhan" dan "faktual" dalam implementasi kabijakan. Pendekatan kepatuhan memusatkan perhatian pada tingkat kepatuhan unit kerja atau individu bawahan terhadap unit kerja atau individu atasan. Perspektif kepatuhan merupakan analisis karakter dan kualitas perilaku organisasi. Pada perspektif kepatuhan, paling tidak terdapat dua kekurangan, yaitu banyaknya faktor non-birokratis yang berpengaruh tetapi justru kurang diperhatikan dan adanya program yang tidak didesain dengan baik. Perspektif kedua adalah perspektif faktual yang berasumsi bahwa terdapat banyak faktor yang mempengaruhi proses implementasi kebijakan yang mengharuskan implementor agar lebih leluasa mengadakan penyesuaian [24].

Implementasi strategi meliputi penentuan sasaran tahunan, menentukan kebijakan, memotivasi karyawan, dan mengalokasikan sumber agar formulasi strategi dapat dieksekusi. Implementasi strategi juga meliputi pengembangan budaya perusahaan yang mendukung strategi, pembuatan struktur organisasi yang efektif, mengarahkan kegiatan pemasaran, menyiapkan anggaran, mengembangkan sistem informasi, dan menghubungkan antara kompensasi karyawan terhadap kinerja organisasi. Implementasi strategi merupakan proses interaktif dalam mengimplementasikan strategi, kebijakan, program, dan rencana tindakan dimana organisasi diperbolehkan menggunakan sumber daya untuk memperoleh keunggulan peluang dalam lingkungan persaingan [23].
Pengaruh strategi terhadap kinerja perusahaan tidak berdiri sendiri, namun dipengaruhi oleh berbagai faktor kontijensi lingkungan eksternal dan lingkungan internal. Pengaruh lingkungan internal dan lingkungan eksternal terhadap strategi dan implikasinya pada kinerja perusahaan merupakan fokus bahasan teori Market Based View (MBV), sedangkan pengaruh kapabilitas terhadap strategi dan implikasinya pada kinerja perusahaan merupakan fokus bahasan teori Resource Based View (RBV) [31].

\section{B. Kerangka Pemikiran}

Beberapa penelitian terdahulu dilakukan untuk menguji keterkaitan antara mekanisme GCG terhadap kinerja perusahaan. Sebagian hasil penelitian terdahulu menunjukkan tidak ada hubungan antara GCG dengan kinerja perusahaan [27]. Penelitian lainnya berkata sebaliknya, bahwa GCG memiliki pengaruh terhadap kinerja perusahaan perbankan. $[11,14,26]$. Penelitian lain menyatakan bahwa perusahaan yang mempunyai poor performance disebabkan oleh poor governance, dengan adanya hubungan positif antara GCG dengan nilai dan kinerja perusahaan [9].

Implementasi strategi merupakan salah satu tahapan manajemen strategis (grand theory penelitian) yang menjadi fokus utama dalam penelitian ini. Beberapa pendekatan middle range theory yang digunakan untuk menjembatani applied theory yang akan dipakai, antara lain :

1. Market Based View (MBV), menyatakan bahwa kinerja perusahaan ditentukan oleh posisi unik perilaku strategis perusahaan dalam menanggapi persaingan pasar. Teori ini menekankan pentingnya peran pasar yang kompetitif sebagai penentu perilaku perusahaan yang kemudian memberikan implikasi pada kinerja perusahaan. [13]. Kinerja perusahaan yang superior tergantung pada posisi unik perusahaan dalam lingkungan kompetitif yang terbentuk dari lima kekuatan persaingan yaitu kekuatan pembeli, ancaman pesaing baru, kekuatan pemasok, ancaman substitusi dan intensitas persaingan. Posisi unik untuk memperoleh keunggulan daya saing dan kinerja superior hanya dapat diperoleh dengan menerapkan salah satu strategi generik yaitu biaya rendah, keunikan produk dan fokus [19].

2. Resource Based View (RBV), suatu pendekatan untuk menciptakan keunggulan kompetitif. Konsep ini berpandangan bahwa organisasi harus mencermati kondisi internal perusahaan untuk menemukan keunggulan internal guna mendeteksi lingkungan kompetitif, mengeksploitasi peluang eksternal dengan memanfaatkan dan meraih kinerja yang lebih tinggi. RBV sangat mengandalkan pada sumber daya dan kemampuan yang unik, valuable, dan sukar ditiru dalam upaya menciptakan keunggulan bersaing. [6]

Sintesa dari berbagai teori dan hasil penelitian terdahulu menghasilkan struktur landasan teori yang dipergunakan untuk penelitian. Grand theory yang digunakan antara lain manajemen strategis (Wheelen dan Hunger, 2018) dan manajemen implementasi (Ripley dan Franklin, 1982), lalu middle range theory yang digunakan yaitu market based view (Hitt, Ireland, Hoskisson, 2004) dan resource based view (Rothaermel, 2013). [30,25,13,6] Applied theory yang merupakan konsep aktual dari teori induknya sebagai kajian substansi di level mikro antara lain budaya perusahaan 
(Muliani, 2014), strategi implementasi good corporate governance (Hadad, 2016) dan keberlangsungan kinerja bank (Civelek, Çemberci, Artar, dan Uca, 2015). [11,17,18] Gambar 2 berikut merupakan struktur landasan teori untuk penelitian yang akan digunakan untuk menganalisis permasalahan dan membentuk hipotesa penelitian. Susunan struktur landasan teori tersebut selanjutnya akan memandu dalam penyusunan kerangka pemikiran penelitian yang akan dijadikan titik tolak pengembangan paradigma dan hipotesis penelitian.

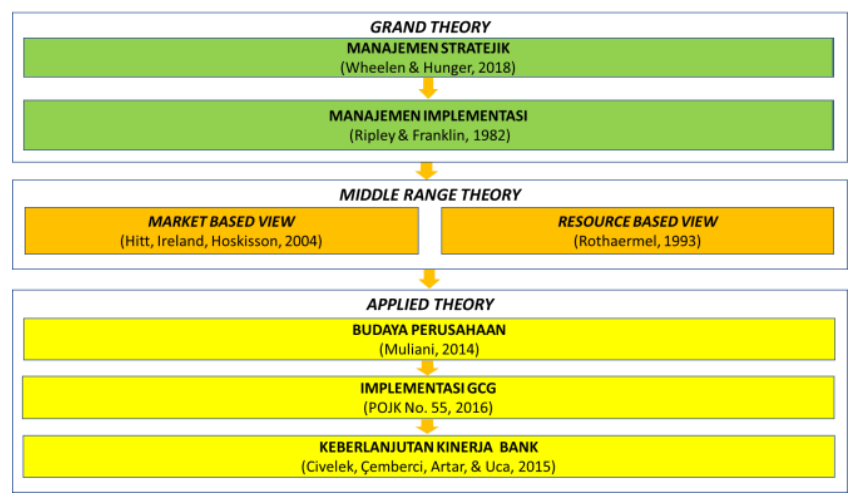

Gambar 2. Struktur Landasan Teori Untuk Penelitian

Berdasarkan fenomena gap, research gap, dan theoretical gap yang telah diuraikan sebelumnya, maka kerangka pemikiran dari penelitian ini dapat dijabarkan sebagaimana Gambar 3 berikut.

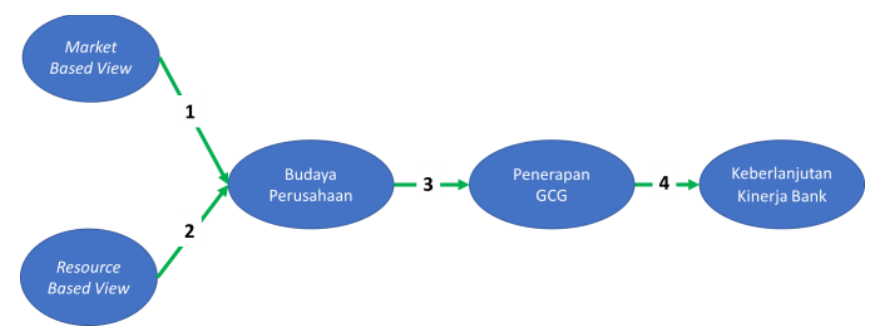

Gambar 3. Kerangka Pemikiran Model Pengaruh Budaya Perusahaan Dalam Mendukung Penerapan Good Corporare Governance Serta Implikasinya Terhadap Keberlanjutan Kinerja Bank

\section{Hipotesis Penelitian}

Menurut Sugiyono (2013), hipotesis merupakan jawaban sementara terhadap rumusan masalah penelitian. Hipotesis juga dapat dinyatakan sebagai jawaban teoritis terhadap rumusan masalah penelitian, belum jawaban yang empirik. [29] Berdasarkan latar belakang masalah dan kerangka pemikiran sebelumnya, maka diajukan hipotesis penelitian sebagai berikut :

1. Terdapat pengaruh market based view terhadap budaya perusahaan.

2. Terdapat pengaruh resource based view terhadap budaya perusahaan.

3. Terdapat pengaruh budaya perusahaan terhadap penerapan Good Corporate Governance.

4. Terdapat pengaruh penerapan Good Corporate Governance terhadap keberlanjutan kinerja bank.

\section{Metode Penelitian}

\section{A. Metode \& Desain Penelitian}

Berdasarkan tujuannya, jenis penelitian ini adalah penelitian deskriptif dan verifikatif yaitu penelitian yang bertujuan untuk mendapatkan gambaran tentang karakteristik variabel penelitian dan mengukur hubungan antar variabel penelitian melalui proses pengujian hipotesis. Penelitian ini juga bertujuan menguji rumusan hipotesis-hipotesis yang menggambarkan hubungan kausal antara dua variabel atau lebih. Oleh karena itu, jenis penelitiannya adalah penelitian verifikatif. Waktu penggalian data primer hanya satu kali dilakukan pada tiap unit sumber data yang sama. Oleh karena penelitian hanya dilakukan satu kali, maka dimensi waktu dalam penelitian ini adalah cross-section.

Pendekatan metode penelitian yang digunakan untuk menguji hipotesis adalah desain model causal research (penelitian sebab-akibat), yaitu suatu model desain riset, dimana penekanannya pada suatu hubungan sebab akibat atau suatu model riset konklusif yang didesain untuk mengumpulkan bukti-bukti hubungan sebab akibat. Selanjutnya, penyelidikan hubungan kausal antar variabel dalam penelitian ini akan digunakan teknik Analisis jalur (Path Analysis), dengan aplikasi Analysis of Moment Structure (AMOS) versi 25. [4]

\section{B. Variabel Penelitian \& Pengukurannya}

Dalam penelitian ini terdapat lima variabel utama (construct variables) dalam model penelitian yang dirancang yaitu Market Based View (MBV), Resource Based View (RBV), dan Budaya Perusahaan (BP) yang merupakan variabel eksogen dalam model, serta Penerapan Good Corporate Governance (PGCG) sebagai variabel antara dan variabel Keberlanjutan Kinerja Bank (KKB) sebagai variabel endogen.

Operasionalisasi variabel dan pengukuran masing-masing variabel penelitian seperti ditunjukkan pada Tabel 4 menggunakan skala Likert dalam pengukuran dimensi atau indikator variabel. Tipe skala Likert paling sering digunakan para peneliti perilaku dan sangat cocok untuk mengukur respons sikap responden terhadap obyek variabel yang diteliti. Selain itu, tipe skala Likert memiliki jenis skala ukur interval [29] Jika skala Likert dinilai masih bersifat ordinal maka untuk menaikkan pengukuran ke interval terlebih dahulu dilakukan proses transformasi data menggunakan teknik Method of Successive Interval (MSI). Selanjutnya, data yang telah berskala interval tersebut diharapkan akan mendukung akurasi dalam membuat estimasi parameter-parameter penelitian yang ditetapkan dalam model Structural Equation Models (SEM).

TABEL 4. OPERASIONALISASI VARIABEL

\begin{tabular}{|c|c|c|c|c|}
\hline VARIABEL & SUB VARIABEL & INDIKATOR & SKALA & NO \\
\hline 1 & 2 & 3 & 4 & $\mathbf{5}$ \\
\hline \multirow{5}{*}{$\begin{array}{c}\text { Keberlanjutan } \\
\text { Kinerja Bank }\end{array}$} & \multirow{2}{*}{ Laba } & Laba Bersih & Interval & 1 \\
\hline & & Rasio Return of Equity (ROE) & Rasio & 2 \\
\hline & Non Performing Loan & Rasio Non Performing Loan & Rasio & 3 \\
\hline & \multirow{2}{*}{ Aset } & Total Aset & Interval & 4 \\
\hline & & Rasio Return of Asset (ROA) & Rasio & 5 \\
\hline
\end{tabular}




\begin{tabular}{|c|c|c|c|c|}
\hline VARIABEL & SUB VARIABEL & INDIKATOR & SKALA & NO \\
\hline \multirow{8}{*}{$\begin{array}{l}\text { Penerapan } \\
\text { GCG }\end{array}$} & \multirow{3}{*}{ Prinsip-Prinsip GCG } & Accountability & Interval & 6 \\
\hline & & Responsibility & Interval & 7 \\
\hline & & Independency & Interval & 8 \\
\hline & \multirow{2}{*}{ Governance Structure } & Struktur Organisasi & Interval & 9 \\
\hline & & Tupoksi Deskripsi Jabatan & Interval & 10 \\
\hline & \multirow{3}{*}{ Governance Outcome } & Tingkat Kesehatan Bank & Interval & 11 \\
\hline & & Profil Risiko & Interval & 12 \\
\hline & & \begin{tabular}{|l} 
Root Cause Credit Risk \\
\end{tabular} & Interval & 13 \\
\hline \multirow{7}{*}{$\begin{array}{l}\text { Budaya } \\
\text { Perusahaan }\end{array}$} & \multirow{3}{*}{ Internal Culture } & Risk Awareness Culture & Interval & 14 \\
\hline & & Compliance Culture & Interval & 15 \\
\hline & & Data Security Awareness & Interval & 16 \\
\hline & \multirow{4}{*}{ Corporate Values } & Service Excellence & Interval & 17 \\
\hline & & Integrity & Interval & 18 \\
\hline & & Respect & Interval & 19 \\
\hline & & Innovation & Interval & 20 \\
\hline \multirow{7}{*}{$\begin{array}{l}\text { Market Based } \\
\quad \text { View }\end{array}$} & \multirow{2}{*}{ Pengawas } & Otoritas Jasa Keuangan & Interval & 21 \\
\hline & & Bank Indonesia & Interval & 22 \\
\hline & \multirow{3}{*}{ Porter's Five Forces } & Standar Industri & Interval & 23 \\
\hline & & \begin{tabular}{|l|} 
Aliansi Strategis \\
\end{tabular} & Interval & 24 \\
\hline & & Cost Leadership & Interval & 25 \\
\hline & \multirow{2}{*}{ PESTEL Analysis } & Financial Technology & Interval & 26 \\
\hline & & Corporate Social Responsibility & Interval & 27 \\
\hline \multirow{14}{*}{$\begin{array}{l}\text { Resource } \\
\text { Based View }\end{array}$} & \multirow{2}{*}{ Balance Score Card } & Internal Business Process & Interval & 28 \\
\hline & & Kerugian Operasional & Interval & 29 \\
\hline & \multirow{2}{*}{ Human Capital } & Learning \& Growth & Interval & 30 \\
\hline & & Individual Score Card & Interval & 31 \\
\hline & \multirow[b]{2}{*}{ Dynamic Capabilities } & Kapabilitas Pemasaran & Interval & 32 \\
\hline & & $\begin{array}{|lc|}\text { Kapabilitas } & \text { Sistem, Teknolog } \\
\text { Informasi \& } & \text { Komunikasi } \\
\end{array}$ & Interval & 33 \\
\hline & \multirow{2}{*}{ Penghargaan } & Penghargaan Pada Unit Kerja & Interval & 34 \\
\hline & & Penghargaan Pada Pegawai & Interval & 35 \\
\hline & \multirow{2}{*}{ Pelayanan } & Role Play & Interval & 36 \\
\hline & & Service Quality Assurance & Interval & 37 \\
\hline & \multirow{4}{*}{ Kepatuhan \& Audit Internal } & Gratifikasi \& APU-PPT & Interval & 38 \\
\hline & & Know Your Customer & Interval & 39 \\
\hline & & Fraud Awareness & Interval & 40 \\
\hline & & Temuan Berulang & Interval & 41 \\
\hline
\end{tabular}

Pengujian hipotesis penelitian dilakukan dengan menggunakan teknik pengujian kuantitatif, oleh karena itu data hasil pengukuran variabel latent (construct variables) dan variabel manifest (observable variables) harus dikonversi ke dalam bentuk kuantitatif. Dalam pengukurannya digunakan seperangkat alat berupa daftar. Katagori penskalaan diawali dari 1 yang mewakili peringkat skala terendah dan sampai 5 untuk mewakili peringkat skor tertinggi.

\section{Populasi \& Sampel Penelitian}

Dalam penelitian yang dijadikan unit analisis dalam penelitian ini adalah para direktur utama dari 134 (seratus tiga puluh empat) bank umum di Indonesia. Karakteristik atribut unit analisis yang akan diteliti relatif homogen yang memiliki tugas baik dari sisi ekspansi bisnis seperti penyaluran kredit, peningkatan fee based income, juga dari sisi pelayanan dan operasional kepada nasabah serta tugas administratif lainnya.

Unit populasi tersebut dapat dikatagorikan sebagai populasi berukuran besar. Oleh sebab itu, didasarkan pada pertimbangan keterbatasan waktu maupun alasan efisiensi operasional, maka penggunaan sampel menjadi pilihan yang paling manageable daripada semua anggota populasi yang diteliti. Pengambilan sampel dari populasi agar diperoleh sampel yang representatif dan dapat mewakili, maka diusahakan agar setiap subjek dalam populasi memiliki peluang yang sama untuk menjadi sampel. Adapun sampel dalam penelitian ini merupakan sebagian dari keseluruhan populasi penelitian. Adapun sampel yang digunakan dalam penelitian ini didapat dengan pengambilan sampel menggunakan teknik non-probability sampling dengan pengambilan sampling sistematis. Non-probability sampling merupakan teknik yang tidak memberi peluang / kesempatan yang sama bagi setiap unsur / populasi untuk dipilih menjadi sampel. [10].

Adapun perhitungan jumlah sampel minimum yang digunakan dalam penelitian ini adalah :

$$
\begin{aligned}
& \mathrm{N}=134, \mathrm{e}=0,05 \\
& \text { Maka diperoleh: } \\
& n=\frac{134}{1+(134)(0.05)^{2}}=\frac{134}{1.335}=100,37 \approx 101
\end{aligned}
$$

Berdasarkan perhitungan sampel minimum dengan menggunakan rumus teknik Slovin, maka diperoleh ukuran sampel (n) yang harus diteliti minimal sebanyak 100,37 sampel yang dibulatkan menjadi 101 unit analisis.

\section{Pemodelan Structural Equation Model}

Dalam penelitian ini pemodelan dirancang dengan menggunakan model persamaan struktural atau Structural Equation Model (SEM). Model persamaan struktural adalah sekumpulan teknik-teknik statistikal yang memungkinkan pengujian serangkaian hubungan yang relatif rumit dan secara simultan. Structural Equation Modeling atau ada yang menyebutnya Linear Structural Relations (LISREL) adalah merupakan pendekatan terintegrasi antara Analisis Faktor, Model Struktural dan Analisis Jalur. Dengan demikian pada dasarnya teknik SEM merupakan kombinasi dari beberapa teknik multivariate yang digunakan untuk menjawab hubungan-hubungan kausal mupun relasional variabel dalam suatu paradigma pemodelan. Beberapa istilah atau terminologi lain teknik SEM yang biasa dijumpai dan termasuk di dalammnya yaitu latent variable modeling, covariance structure analysis, confirmatory factor analysis dan linear structural relationships [23]

Tujuan akhir dari SEM adalah mendapatkan konfirmasi nilai-nilai parameter dan variance dari variabel-variabel yang tercakup dalam model struktural. Model tersebut pada prinsipnya merupakan deivasi dari penjelasan dan konsep (basic concept) serta hubungan variabel-variabelnya dari suatu fenomena atau permasalahan ke dalam bentuk visualisasi diagram yang lebih mudah untuk dimengerti. Dari model struktural tersebut menggambarkan secara jelas hubungan kausal antara variabel independen dengan variabel dependen atau latent variable (construct variable) dengan observable variable (measured variable) maupun hubunganhubungan relasional antar variabel lainnya secara menyeluruh. Dalam kaitannya dengan pengujian hipotesis penelitian, SEM merupakan salah satu metode analisis yang berkenaan dengan model struktural dan path analysis (analisis jalur) [28].

Model struktural hubungan antara variabel eksogen dan endogen, variabel dimensi, dan variabel kesalahan dapat dilihat pada Gambar 4 sebagai berikut. 


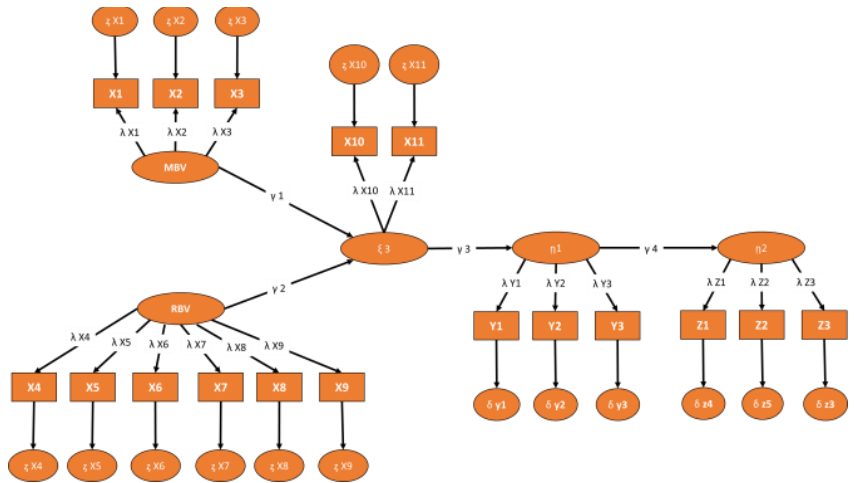

Gambar 4. Model Struktural Hubungan Variabel Latent (Eksogen \& Endogen), Variabel Dimensi (Indikator), \& Variabel Kesalahan (Error)

Model SEM merupakan model pendekatan yang mengintegrasikan sekaligus teknik analisis faktor, model struktural dan analisis jalur. Oleh karena itu dalam analisis SEM tidak ada alat uji statistik tunggal untuk mengukur atau menguji hipotesis mengenai model. [1] Untuk mengukur derajat kesesuaian antara model yang dihipotesiskan dengan data yang disajikan, maka perlu dilakukan uji keseusaian model. Beberapa teknik sebagai alat pengujian dan alat untuk mengetahui apakah SEM telah sesuai untuk menguji hipotesis-hipotesis parameter dalam model antara lain yaitu Chi Square Statistic $\left(\chi^{2}\right)$, The Root Means Square Error of Approximation (RMSA), Goodness of Fit Index (GFI), Adjusted Goodness of Fit Index (AGFI), CMIN/DF (The Sample Discrepancy dibagi dengan Degree of Freedom), Normed Fit Index (NFI), Comparative Fit Index (CFI), Relative Fit Index (RFI), Incremental Fit Index (IFI) dan Tuker-Lewis Index (TLI). Adapun nilai cut-off (batas) indeks kriteria tiap-tiap teknik uji kesesuaian adalah seperti terlihat pada Tabel 5 berikut ini.

TABEL 5. GOODNESS OF FIT CRITERION INDEX

\begin{tabular}{|c|c|c|}
\hline No & Goodness of Fit Index & Cut-off Value \\
\hline 1 & $\chi^{2}-$ Chi-square & Diharapkan kecil \\
\hline 2 & Significance Probability (P) & $\geq 0,05$ \\
\hline 3 & CMIN/DF & $\leq 2,00$ \\
\hline 4 & GFI & $\geq 0,90$ \\
\hline 5 & AGFI & $\geq 0,90$ \\
\hline 6 & NFI & $\geq 0,90$ \\
\hline 7 & CFI & $\geq 0.95$ \\
\hline 8 & RFI & $\geq 0,90$ \\
\hline 9 & IFI & $\geq 0.95$ \\
\hline 10 & TLI & $\leq 0,08$ \\
\hline 11 & RMSEA & \\
\hline
\end{tabular}

\section{HASIL DAN PEMBAHASAN}

\section{A. Deskripsi Hasil Pengukuran Variabel Penelitian}

Perumusan atau pernyataan hipotesis-hipotesis yang telah dirumuskan dari struktur hubungan variabel konstruk atau laten dapat dilakukan pengujian setelah dilakukan pengukuran dimensi atau indikator dari masing-masing variabel konstruk selesai dilakukan. Variasi nilai data pada dimensi atau indikator akan menggambarkan variasi variabel konstruknya. Kuat atau lemahnya hubungan berbagai indikator dengan variabel konstruk ditunjukkan oleh besar kecilnya nilai faktor bobot (loading factor) yang dimiliki oleh masing-masing dimensi atau indikator dari variabel konstruknya.

Dalam model SEM keragaman loading factor dapat diketahui melalui analisis faktor konfirmatory (Confirmatory
Factor Analysis / CFA), yaitu ditunjukkan oleh koefisien parameter $\lambda$ (lamda) pada setiap dimensi / indikator. Nilai loading factor yang dimiliki oleh suatu dimensi / indikator minimal $\lambda=0,40$ menggambarkan bahwa dimensi / indikator tersebut memiliki keterikatan atau hubungan yang kuat dan layak diterima menjadi komponen faktor suatu variabel konstruk / latent [8]. Dari output program AMOS Versi 25, estimasi parameter lamda adalah sama dengan estimasi nilai parameter regresi yang terstandarisasi (standardized regression weigth). atau disebut sebagai koefisien jalur (path coefficient). Dengan diketahuinya besaran nilai koefisen jalur maka perhitungan seberapa besar nilai pengaruh struktural secara langsung, tidak langsung maupun pengaruh total dari variabel prediktor terhadap prediktannya dapat diketahui dan ditentukan. Adapun besaran nilai koefisien hasil estimasi parameter lamda $\mathrm{X}$, lamda $\mathrm{Y}$, dan lamda $\mathrm{Z}$ terlihat di dalam Tabel 6 berikut ini.

TABEL 6. NILAI HASIL ESTIMASI PARAMETER LAMDA (LOADING FACTOR) PADA MASING-MASING DIMENSI / INDIKATOR VARIABEL EKSOGEN DAN ENDOGEN DALAM MODEL PENELITIAN

\begin{tabular}{|c|c|c|c|}
\hline Variabel Eksogen & Nilai $\lambda$ & Variabel Endogen & Nilai $\lambda$ \\
\hline $\begin{array}{l}\text { Market Based View (MBV) } \\
\text { - Pengawas }\left(\mathrm{X}_{1}\right) \\
\text { - Porter's Five Forces }\left(\mathrm{X}_{2}\right) \\
\text { - PESTEL Analysis }\left(\mathrm{X}_{3}\right)\end{array}$ & $\begin{array}{l}0.989 \\
0.875 \\
0.744\end{array}$ & $\begin{array}{l}\text { Penerapan GCG } \\
\text { (PGCG) } \\
\text { - } \quad \text { Prinsip-prinsip } \\
\text { GCG }\left(\mathrm{Y}_{1}\right) \\
\text { - } \quad \text { Governance } \\
\quad \text { Structure }\left(\mathrm{Y}_{2}\right) \\
\text { - Governance } \\
\text { Outcome }\left(\mathrm{Y}_{3}\right)\end{array}$ & $\begin{array}{l}0.846 \\
0.780 \\
0.925\end{array}$ \\
\hline $\begin{array}{l}\text { Resource Based View }(\mathrm{RBV}) \\
\text { - Balanced Score Card }\left(\mathrm{X}_{4}\right) \\
\text { - Human Capital }\left(\mathrm{X}_{5}\right) \\
\text { - Dynamic Capabilities }\left(\mathrm{X}_{6}\right) \\
\text { - Penghargaan }\left(\mathrm{X}_{7}\right) \\
\text { - Pelayanan }\left(\mathrm{X}_{8}\right) \\
\text { - Kepatuhan \& Audit } \\
\text { Internal }\left(\mathrm{X}_{9}\right)\end{array}$ & $\begin{array}{l}0.878 \\
0.844 \\
0.868 \\
0.742 \\
0.867 \\
0.746\end{array}$ & $\begin{array}{l}\text { Keberlanjutan } \\
\text { Kinerja Bank (KKB) } \\
\text { - } \quad \text { Laba }\left(\mathrm{Z}_{1}\right) \\
\text { - } \quad \text { Non Performing } \\
\quad \text { Loan }\left(\mathrm{Z}_{2}\right) \\
\text { - } \\
\text { Asset }\left(\mathrm{Z}_{3}\right)\end{array}$ & $\begin{array}{l}0.887 \\
0.862 \\
0.852\end{array}$ \\
\hline $\begin{array}{l}\text { Budaya Perusahaan }(\mathrm{BP}) \\
\text { - } \quad \text { Internal Culture }\left(\mathrm{X}_{10}\right) \\
\text { - } \quad \text { Corporate Culture }\left(\mathrm{X}_{11}\right)\end{array}$ & $\begin{array}{l}0.757 \\
0.688 \\
\end{array}$ & & \\
\hline
\end{tabular}

Nilai hasil estimasi parameter $\lambda$, baik untuk indikator eksogen maupun variabel endogen semuanya menunjukkan koefisien lebih besar dari 0,40 dan signifikan pada $\alpha=0,05$, artinya bahwa dimensi atau indikator (measured variables) tersebut merupakan faktor yang valid dan reliabel pada setiap variabel latent atau konstruknya.

\section{B. Hasil Uji Kesesuaian Model (Goodness of Fit Test)}

Kelayakan model penelitian yang dikembangkan sangat menentukan kualitas hasil penelitian yang diperoleh. Semakin tinggi tingkat kesesuaian data dengan disain model penelitian yang akan dipergunakan untuk menjelaskan hubungan antar variabel yang terstruktur di dalam model tersebut diharapkan dapat menghasilkan informasi atau temuan baru yang lebih handal dan dapat dipercaya.

Dengan tingkat goodness of fit model yang semakin tinggi, maka tingkat akurasi proses dan hasil penelitian akan semakin akurat dan terjamin serta mampu memberikan hasil temuan dan kesimpulan penelitian yang semakin baik dan dapat dipercaya. Salah satu cara yang paling praktis untuk mengetahui dan mengukur tingkat kesesuaian model SEM yaitu dapat ditelusuri dari nilai koefisien alat-alat statistik dan 
non statistik untuk menilai atau mengevaluasi kelayakan model yang dikembangkan.

Dalam penelitian ini digunakan alat diteksi LikehoodRatio Chi-Square $\left(\chi^{2}\right)$, merupakan alat uji yang sangat cocok untuk mengukur overall fit model. Model $\chi^{2}$ digunakan untuk mendeteksi atau mengetahui tingkat perbedaan matrix covarians atau matrik korelasi yang diobservasi (diamati) dengan yang diestimasi. Alat uji kesesuaian lain yang akan dipergunakan adalah CMIN/DF, NFI, AGFI,CFI, IFI, RFI, RMSEA, dan TLI. Besaran koefisien hasil uji kelayakan dalam model penelitian dapat dicermati pada Tabel 7 sebagai berikut ini.

TABEL 7. HASIL UJi KeSESUAIAN MODEL

\begin{tabular}{clccc}
\hline No & $\begin{array}{c}\text { Teknik Pengujian } \\
\text { Kesesuaian Model }\end{array}$ & $\begin{array}{c}\text { Nilai } \\
\text { Kritis }\end{array}$ & $\begin{array}{c}\text { Hasil } \\
\text { Model }\end{array}$ & $\begin{array}{c}\text { Evaluasi } \\
\text { Model }\end{array}$ \\
\hline 1 & Chi-square $\left(\chi^{2}\right)$ & 212.80 & 133.784 & Fit \\
2 & Probability & $\geq 0,05$ & 0,000 & Fit \\
3 & CMIN / DF & $\leq 2,00$ & 3,793 & Fit \\
4 & GFI & $\geq 0,90$ & 0,944 & Fit \\
5 & AGFI & $\geq 0,90$ & 0,932 & Fit \\
6 & NFI & $\geq 0,90$ & 0,902 & Fit \\
7 & IFI & $\geq 0,90$ & 0,926 & Fit \\
8 & CFI & $\geq 0,95$ & 0,995 & Fit \\
9 & RFI & $\geq 0,90$ & 0,972 & Fit \\
10 & TLI & $\leq 0,08$ & 0,952 & Fit \\
11 & RMSEA & & 1401 & Fit \\
12 & DF & Sumber : Hasil Pengolahan Data Menggunakan Program AMOS Versi 25
\end{tabular}

Berdasarkan hasil yang disajikan pada Tabel 7 memperlihatkan bahwa hampir semua koefisien hasil uji kesesuaian dapat dikatagorikan memenuhi kriteria atau syarat kelayakan model. Chi-square sebagai alat uji yang paling mendasar untuk mengukur overall fit model, memiliki koefisien $\chi^{2}$ sebesar 133,784 lebih kecil dari nilai $\chi^{2}(\mathrm{df}=134$, $\mathrm{p}=0,05)$ sebesar 212,80 dan memiliki nilai probabilitas sebesar $\mathrm{p}=0,00$ memenuhi syarat kesesuaian model.

Sementara untuk ukuran nilai kesesuaian atau kelayakan model lainnya yaitu CMIN / DF $=3,793$, GFI = 0,944, AGFI $=0,932$, NFI $=0,902, \mathrm{IFI}=0,926, \mathrm{CFI}=0,925$, RFI $=0,972$, TLI $=0,952$, dan RMSEA $=0,101$ sudah memenuhi kriteria nilai kritis (critical value) model fit yang telah ditetapkan. Dari indikator-indikator evaluasi uji kecocokan model tersebut secara umum menunjukkan indikasi kecenderungan adanya informasi yang cukup kuat untuk menyimpulkan bahwa model yang dikembangkan telah sesuai dan layak untuk diterima pada penelitian yang sedang dikembangkan ini.

\section{Analisis Model Penelitian}

Sebelum melaksanakan pengujian hipotesis, dilakukan pengujian model terlebih dahulu dengan mengadakan analisis model pengukuran masing-masing variabel. Variabel yang akan dianalis dan diukur adalah Market Based View, Resource Based View, Budaya Perusahaan, Penerapan GCG, dan Keberlanjutan Kinerja Bank.

Proses pengolahan data hasil penelitian dilakukan dengan menggunakan aplikasi AMOS Versi 25. Setelah melalui serangkaian proses uji asumsi yang melandasi model SEM, dari hasil pengolahan data tersebut diperoleh output atau hasil antara lain estimasi matrik korelasi, matriks kovarian, dan estimasi parameter-parameter struktural yang dirumuskan dalam hipotesis. Pengujian hipotesis merupakan pembuktian atau pengujian statistik terhadap semua yang telah dirumuskan dalam hipotesis penelitian yang didasarkan pada kajian pustaka dan pengembangan teori [31]. Dari hasil pengujian hipotesis tersebut diharapkan dapat diperoleh temuan-temuan data baru yang selanjutnya dianalisis untuk menarik beberapa kesimpulan dan beberapa saran atau rekomendasi.

Hasil estimasi parameter atau koefisien regresi secara lengkap dari model penuh (full model) disajikan pada Gambar 5 berikut ini.

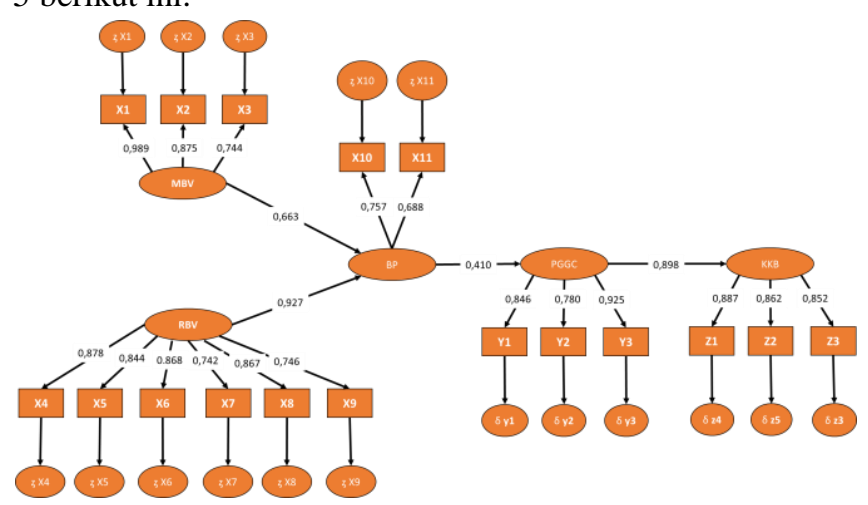

Gambar 5. Model Penuh Penelitian \& Hasil Estimasi Parameter Struktural Dari Data Terstandarisasi (Standarized Estimates)

Struktur lengkap hubungan variabel dan hasil estimasi parameter dalam model penelitian penuh terstandarisasi dapat dilihat pada Tabel 8 berikut.

TABEL 8. STRUKTUR HUBUNGAN VARIABEL DAN HASIL ESTIMASI PARAMETER DALAM MODEL PENELITIAN PENUH

\begin{tabular}{|c|c|c|c|c|c|c|c|}
\hline \multicolumn{2}{|c|}{$\begin{array}{c}\text { Struktur Hubungan } \\
\text { Variabel }\end{array}$} & \multicolumn{5}{|c|}{$\begin{array}{c}\text { Unstandardardized } \\
\text { Estimate }\end{array}$} \\
\cline { 4 - 7 } & Estimate & S.E. & C.R. & P & 0,663 \\
\hline BP & $\leftarrow$ & MBV & 0,581 & 0,041 & 9,364 & $* * *$ & 0,927 \\
\hline BP & $\leftarrow$ & RBV & 0,953 & 0,108 & 8,844 & $* * *$ & 0,410 \\
\hline PGCG & $\leftarrow$ & BP & 0,200 & 0,033 & 6,106 & $* * *$ & 0,898 \\
\hline KKB & $\leftarrow$ & PGCG & 0,766 & 0,109 & 8,051 & $* * *$ & 0,989 \\
\hline X1 & $\leftarrow$ & MBV & 1,000 & 0,035 & 14,430 & $* * *$ & 0,875 \\
\hline X2 & $\leftarrow$ & MBV & 0,790 & 0,042 & 11,552 & $* * *$ & 0,744 \\
\hline X3 & $\leftarrow$ & MBV & 1,000 & 0,003 & 17,860 & $* * *$ & 0,878 \\
\hline X4 & $\leftarrow$ & RBV & 0,881 & 0,094 & 9,335 & $* * *$ & 0,844 \\
\hline X5 & $\leftarrow$ & RBV & 0,873 & 0,113 & 11,310 & $* * *$ & 0,868 \\
\hline X6 & $\leftarrow$ & RBV & 0,788 & 0,123 & 11,241 & $* * *$ & 0,742 \\
\hline X7 & $\leftarrow$ & RBV & 0,821 & 0,117 & 11,318 & $* * *$ & 0,867 \\
\hline X8 & $\leftarrow$ & RBV & 0,667 & 0,114 & 11,147 & $* * *$ & 0,746 \\
\hline X9 & $\leftarrow$ & RBV & 0,828 & 0,116 & 11,410 & $* * *$ & 0,757 \\
\hline X10 & $\leftarrow$ & BP & 0,659 & 0,107 & 10,317 & $* * *$ & 0,688 \\
\hline X11 & $\leftarrow$ & BP & 0,497 & 0,122 & 13,142 & $* * *$ & 0,846 \\
\hline Y1 & $\leftarrow$ & PGCG & 1,000 & 0,098 & 9,858 & $* * *$ & 0,780 \\
\hline Y2 & $\leftarrow$ & PGCG & 1,065 & 0,116 & 9,171 & $* * *$ & 0,925 \\
\hline Y3 & $\leftarrow$ & PGCG & 1,087 & 0,081 & 13,374 & $* * *$ & 0,887 \\
\hline Z1 & $\leftarrow$ & KKB & 1,000 & 0,081 & 15,659 & $* * *$ & 0,862 \\
\hline Z2 & $\leftarrow$ & KKB & 1,031 & 0,059 & 17,370 & $* * *$ & 0,852 \\
\hline Z3 & $\leftarrow$ & KKB & 0,979 & 0,060 & 16,233 & $* * *$ & \\
\hline
\end{tabular}

\section{Hasil Pengujian Parameter $\lambda$ (Loading Factor)}

Parameter $\lambda$ atau loading factor merupakan koefisien regresi terstandarisasi (standardized regression weigth) pada model pengukuran baik untuk variabel eksogen maupun variabel endogen. Berdasarkan hasil pethitungan dan pengolahan data diperoleh koefisien persamaan regresi terstandarisasi untuk model pengukuran yaitu $\lambda \mathrm{X}_{1} \mathrm{~s} / \mathrm{d} \lambda \mathrm{X}_{11}$ untuk variabel eksogen dan $\lambda \mathrm{Y}_{1} \mathrm{~s} / \mathrm{d} \lambda \mathrm{Y}_{3}$ serta $\lambda \mathrm{Z}_{1} \mathrm{~s} / \mathrm{d} \lambda \mathrm{Z}_{3}$ 
untuk variabel endogen seluruhnya memiliki koefisien positif di atas 0,40 , dimana hipotesis parameter $\lambda$ (Loading factor) adalah :

$\begin{array}{ll}\text { 1. } & \mathrm{H}_{0}: \lambda \leq 0,40 \text { (Ditolak) } \\ \text { 2. } & \mathrm{H}_{1}: \lambda>0,40 \text { (Diterima) }\end{array}$

Ukuran signifikansi parameter-parameter digambarkan pada besarnya Critical Ratio (CR) dan probabilitasnya (P). Berdasarkan hasil komputasi dengan bantuan program software AMOS Versi 25 yang disajikan pada Tabel 8, menunjukkan koefisien regresi tidak terstandarisasi (unstrandardized regression weigth) pada seluruh persamaan measurement model seluruhnya memiliki nilai positif sangat signifikan $(C R>0.30$ dan $\mathrm{P}>0,010$, dengan demikian dapat disimpulkan bahwa variabel / dimensi $\mathrm{X}_{1}-\mathrm{X}_{11}, \mathrm{Y}_{1}-\mathrm{Y}_{3}$, dan $\mathrm{Z}_{1}-\mathrm{Z}_{3}$ merupakan dimensi-dimensi kuat atau reliabel bagi masing-masing variabel latent-nya.

\section{E. Hasil Pengujian Hipotesis}

Hasil pengujian Hipotesis pertama yaitu "Terdapat pengaruh market based view terhadap budaya perusahaan" dapat dilihat pada bagan struktur hubungan antar variabel berdasarkan rangkuman hasil estimasi parameter sebagaimana Gambar 6 dan Tabel 9 berikut.

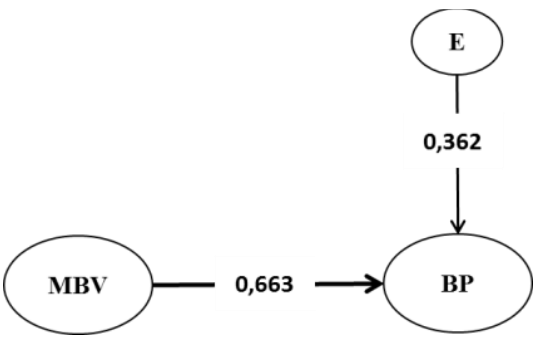

Gambar 6. Pengaruh Market Based View Terhadap Budaya Perusahaan

Tabel 9. Hasil Pengujian Market BASED VIEW, $\mathrm{R}^{2}$, DAN KESIMPULANNYA

\begin{tabular}{|c|c|c|c|c|c|c|c|}
\hline Parameter & Estimasi & $\mathbf{T}_{\text {hitung }}$ & Prob. & $\mathbf{T}_{\text {Tabel }}$ & $\mathbf{F}_{\text {hitung }}$ & $\mathbf{F}_{\text {Tabel }}$ & Ke putusan \\
\hline$\gamma_{1}$ & 0,663 & 21,800 & 0,000 & 2,34 & & & $\mathrm{H}_{0}$, Ditolak \\
\hline $\mathrm{R}^{2}$ & 0,638 & & & & 475,25 & 3,00 & $\mathrm{H}_{0}$, Diterima \\
\cline { 7 - 8 } & & & & & & $\mathrm{H}_{1,}$ Diterima \\
\hline
\end{tabular}

Hasil pengujian 1 terkait pengaruh market based view terhadap budaya perusahaan dapat dilihat pada hipotesis berikut :

1. $\mathrm{H}_{0}: \gamma_{1} \leq 0$

2. $\mathrm{H}_{1}: \gamma_{1}>0$

Koefisien estimasi parameter $\gamma_{1}$ adalah 0,663 , signifikan pada nilai $t_{\text {hitung }}=21,800$ dan probabilitas 0,000 , hal ini berarti parameter $\gamma_{1}$ teruji yaitu menerima $\mathrm{H}_{1}$ dan menolak $\mathrm{H}_{0}$, artinya market based view (MBV) memiliki pengaruh positif yang sangat berarti terhadap budaya perusahaan (BP). Besarnya pengaruh market based view (MBV) terhadap budaya perusahaan $(\mathrm{BP})$ yaitu $0,663 \times 0.663 \times 100 \%=$ $43,96 \%$.

Hasil pengujian Hipotesis kedua yaitu "Terdapat pengaruh resource based view terhadap budaya perusahaan" dapat dilihat pada bagan struktur hubungan antar variabel berdasarkan rangkuman hasil estimasi parameter sebagaimana Gambar 7 dan Tabel 10 berikut.

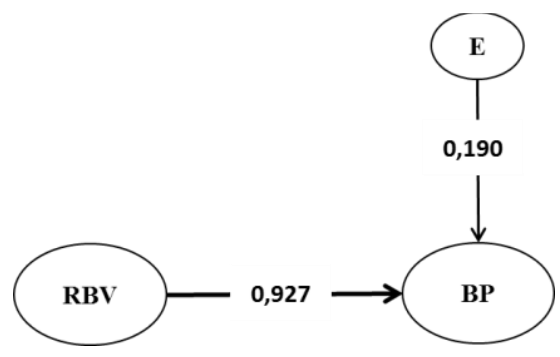

Gambar 7. Pengaruh Resource Based View Terhadap Budaya Perusahaan

Tabel 10. Hasil Pengujian Resource Based VieW, $\mathrm{R}^{2}$, DAN KESIMPULANNYA

\begin{tabular}{|c|c|c|c|c|c|c|c|}
\hline Parameter & Estimasi & $\mathbf{T}_{\text {hitung }}$ & Prob. & $\mathbf{T}_{\text {Tabel }}$ & $\mathbf{F}_{\text {hitung }}$ & $\mathbf{F}_{\text {Tabel }}$ & Keputusan \\
\hline$\gamma_{2}$ & 0,927 & 11,092 & 0,000 & 2,34 & & & $\mathrm{H}_{0}$, Ditolak \\
\cline { 7 - 8 } & & & & & & $\mathrm{H}_{1}$ Diterima \\
\hline $\mathrm{R}^{2}$ & 0,810 & & & & 322.632 & 3,00 & $\mathrm{H}_{0}$, Ditolak \\
\cline { 8 - 8 } & & & & & $\mathrm{H}_{1, \text { Diterima }}$ \\
\hline
\end{tabular}

Hasil pengujian 2 terkait pengaruh resource based view terhadap budaya perusahaan dapat dilihat pada hipotesis berikut :

1. $\mathrm{H}_{0}: \gamma_{1} \leq 0$

2. $\mathrm{H}_{1}: \gamma_{1}>0$

Koefisien estimasi parameter $\gamma_{2}$ adalah 0,927 , signifikan pada nilai thitung $=11,092$ dan probabilitas 0,000 , hal ini berarti parameter $\gamma_{2}$ teruji yaitu menerima $\mathrm{H}_{1}$ dan menolak $\mathrm{H}_{0}$, artinya resource based view (RBV) memiliki pengaruh positif yang sangat berarti terhadap budaya perusahaan (BP). Besarnya pengaruh resource based view (RBV) terhadap budaya perusahaan (BP) yaitu $0,927 \times 0.927 \times 100 \%=$ $85,93 \%$.

Hasil pengujian Hipotesis ketiga yaitu "Terdapat pengaruh budaya perusahaan terhadap penerapan Good Corporate Governance" dapat dilihat pada bagan struktur hubungan antar variabel berdasarkan rangkuman hasil estimasi parameter sebagaimana Gambar 8 dan Tabel 11 berikut.

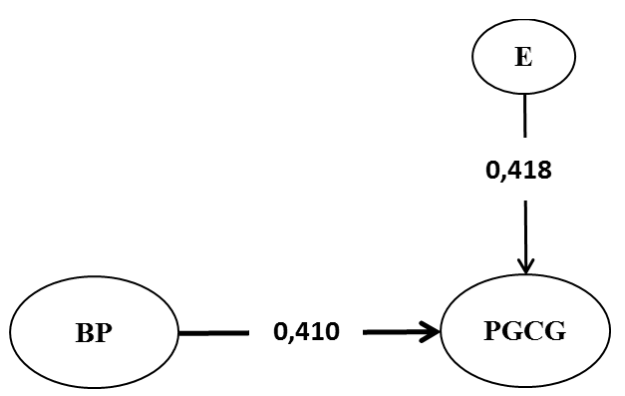

Gambar 8. Pengaruh Budaya Perusahaan Terhadap Penerapan GCG

Tabel 11. Hasil Pengujian Budaya PerusahaAn, R², DaN KESIMPULANNYA

\begin{tabular}{|c|l|l|l|l|l|l|l|}
\hline Parameter & Estimasi & $\mathbf{T}_{\text {hitung }}$ & Prob. & $\mathbf{T}_{\text {Tabel }}$ & $\mathbf{F}_{\text {hitung }}$ & $\mathbf{F}_{\text {Tabel }}$ & Ke putusan \\
\hline$\gamma_{3}$ & 0,410 & 4,373 & 0,000 & 2,34 & & & $\mathrm{H}_{0}$, Ditolak \\
\hline & & & & & & & $\mathrm{H}_{1}$ Diterima \\
\hline $\mathrm{R}^{2}$ & 0,582 & & & & 187.446 & 3,00 & $\mathrm{H}_{0}$, Ditolak \\
\cline { 7 - 8 } & & & & & & $\mathrm{H}_{1}$ Diterima \\
\hline
\end{tabular}

Hasil pengujian 3 terkait pengaruh budaya perusahaan terhadap penerapan GCG dapat dilihat pada hipotesis berikut: 
1. $\mathrm{H}_{0}: \gamma_{1} \leq 0$

2. $\mathrm{H}_{1}: \gamma_{1}>0$

Koefisien estimasi parameter $\gamma_{3}$ adalah 0,410 , signifikan pada nilai $t_{\text {hitung }}=4,373$ dan probabilitas 0,000 , hal ini berarti parameter $\gamma_{3}$ teruji yaitu menerima $\mathrm{H}_{1}$ dan menolak $\mathrm{H}_{0}$, artinya budaya perusahaan (BP) memiliki pengaruh positif yang sangat berarti terhadap penerapan GCG (PGCG). Besarnya pengaruh budaya perusahaan (BP) terhadap penerapan GCG (PGCG) yaitu 0,410 X $0.410 \times 100 \%=$ $16,81 \%$.

Hasil pengujian Hipotesis keempat yaitu "Terdapat pengaruh penerapan Good Corporate Governance terhadap penerapan keberlanjutan kinerja bank" dapat dilihat pada bagan struktur hubungan antar variabel berdasarkan rangkuman hasil estimasi parameter sebagaimana Gambar 9 dan Tabel 12 berikut.

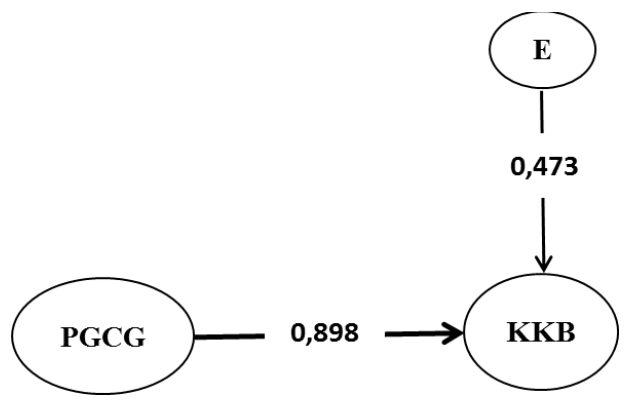

Gambar 9. Pengaruh Penerapan GCG Terhadap Keberlanjutan Kinerja Bank

TABel 12. Hasil Pengujian Penerapan GCG, R², DAN Kesimpulannya

\begin{tabular}{|c|c|c|c|c|c|c|l|}
\hline Parameter & Estimasi & $\mathbf{T}_{\text {hitung }}$ & Prob. & $\mathbf{T}_{\text {Tabel }}$ & $\mathbf{F}_{\text {hitung }}$ & $\mathbf{F}_{\text {Tabel }}$ & Ke putusan \\
\hline$\eta^{1}$ & 0,898 & 17,358 & 0,000 & 2,34 & & & $\mathrm{H}_{0}$, Ditolak \\
\hline & & & & & & & $\mathrm{H}_{1,}$ Diterima \\
\hline $\mathrm{R}^{2}$ & 0,527 & & & & 187.446 & 3,00 & $\mathrm{H}_{0}$, Ditolak \\
\cline { 7 - 8 } & & & & & & $\mathrm{H}_{1, \text { Diterima }}$ \\
\hline
\end{tabular}

Koefisien estimasi parameter $\eta_{1}$ adalah 0,989 , signifikan pada nilai $t_{\text {hitung }}=17,358$ dan probabilitas 0,000 , hal ini berarti parameter $\eta_{1}$ teruji yaitu menerima $\mathrm{H}_{1}$ dan menolak $\mathrm{H}_{0}$, artinya penerapan GCG (PGCG) memiliki pengaruh positif yang sangat berarti terhadap keberlanjutan kinerja bank (KKB). Besarnya pengaruh penerapan GCG (PGCG) terhadap keberlanjutan kinerja bank (KKB) yaitu 0,898 X $0.898 \times 100 \%=80,64 \%$.

\section{KESIMPULAN DAN SARAN}

Berdasarkan analisis kajian pengaruh Budaya Perusahaan dalam mendukung Penerapan Good Corporare Governance serta implikasinya terhadap Keberlanjutan Kinerja Bank, maka dapat disimpulkan beberapa hal sebagai berikut :

1. Terdapat pengaruh positif dari market based view terhadap budaya perusahaan pada industri perbankan nasional Indonesia. PT Bank Pembangunan Daerah Jawa Barat dan Banten, Tbk. Dalam hal ini, dimensi Pengawas menunjukkan pengaruh tertinggi dalam merefleksikan lingkungan eksternal pada industri perbankan nasional, mengingat industri perbankan merupakan industri khusus yang harus diatur dengan kebijakan yang ketat (high regulated industry).

2. Terdapat pengaruh positif dari resource based view terhadap budaya perusahaan pada industri perbankan nasional. Dimensi balanced score card menunjukkan pengaruh tertinggi dalam merefleksikan resource based view pada industri perbankan nasional. Hal ini menunjukkan bahwa balanced score card berperan lebih besar dalam membentuk budaya perusahaan. Balanced score card merupakan indikator penilaian kinerja dari setiap unit kerja berdasarkan empat perspektif utama yaitu financial perspective, customer perspective, internal business process perspective, dan learning and growth perspective.

3. Terdapat pengaruh positif dari budaya perusahaan terhadap penerapan GCG pada industri perbankan nasional. Dimensi internal culture menunjukkan pengaruh tertinggi dalam merefleksikan budaya perusahaan pada penerapan GCG. Hal tersebut menunjukkan bahwa strategi implementasi GCG dapat berjalan jika didukung oleh budaya-budaya internal yang lebih kuat pengaruhnya daripada budaya perusaahaan, seperti budaya kolaborasi, budaya sadar risiko, budaya kepatuhan, budaya keamanan informasi, budaya service excellence, budaya zero fraud awaresss, dan budaya-budaya internal lainnya.

4. Terdapat pengaruh positif dari penerapan GCG terhadap keberlanjutan kinerja bank pada industri perbankan nasional di Indonesia. Dalam hal ini, dimensi governance outcome menunjukkan pengaruh tertinggi dalam merefleksikan strategi implementasi GCG untuk menciptakan keberlanjutan kinerja pada industri perbankan nasional. Penerapan governance outcome ditunjukkan dengan adanya kewajiban pelaporan Tingkat Kesehatan Bank dan Profil Risiko kepada regulator (OJK). Hal ini selaras dengan dimensi pengawas yang dominan mempengaruhi variabel market based view pada industri perbankan nasional.

Berdasarkan uraian pada bagian pembahasan dan kesimpulan di atas, maka direkomendasikan beberapa saran praktis sebagai berikut :

1. Dari sisi Governance Structure :

a. Melakukan pengisian kekosongan pegawai khususnya Pejabat Eksekutif

b. Optimalisasi fungsi kepatuhan, manajemen risiko, dan audit internal dalam penangangan kredit bermasalah dan fraud

2. Dari sisi Governance Process :

a. Optimalisasi fungsi Quality Assurance dan Corrective Action terhadap pelanggaran atas ketentuan yang berlaku dan temuan berulang

b. Memaksimalkan fungsi Kontrol Internal Cabang dan Kontrol Internal Wilayah untuk mendukung pelaksanaan Quality Assurance kegiatan operasional di Kantor Cabang yang bertujuan untuk meminimalisasi pelanggaran terhadap ketentuan yang berlaku 
3. Dari sisi Governance Outcome :

a. Penilaian profil risiko harus menunjukkan hasil yang sebenarnya sesuai dengan data/informasi yang disampaikan oleh Kantor Pusat dan/atau Kantor Cabang

b. Pelaporan atas pelaksanaan Know Your Customer, pencegahan praktek APU-PPT, gratifikasi dan/atau transaksi keuangan mencurigakan

\section{REFERENCES}

[1] A. Ferdinand, "Metode Penelitian Manajemen : Pedoman Penelitian Untuk Skripsi, Tesis dan Disertasi Ilmu Manajemen", Universitas Diponegoro, Semarang, 2006

[2] Bisnis Indonesia, "GCG Perbankan Memburuk", Edisi Agustus 2018, Jakarta, 2018

[3] D. J. Teece, "Explicating Dynamic Capalilities: The Nature And Microfoundations of (Sustainable) Enterprise Performance", Strategic Management Journal, Vol. 28, No. 2, pp. 1319-1350, 2007

[4] D. Suryanto, "Pengaruh Ketertarikan, Kemiripan Persepsi, Kemiripan Demografis Atasan Bawahan, Kepuasan Kerja, dan Komitmen Organisasional Terhadap Nilai Prestasi Kerja Bawahan : Suatu Studi di PT Pos Indonesia", Disertasi, Pasca Sarjana Universitas Padjadjaran, Bandung, 2005

[5] E. Sunarwan, "Pengaruh Good Corporate Government (GCG) Terhadap Kinerja Keuangan Perbankan Syariah", Universitas Islam Negeri Syarif Hidayatullah, Jakarta, 2015

[6] F. T. Rothaermel, "Strategic Management: Concepts and Cases", McGraw-Hill, New York, 2013

[7] Hedwigis, "Implementation of Corporate Governance Influence to Earing Management”, Vol. 219, pp. 632-638, 2016, https://doi.org/10.1016/j.sbspro.2016.05.044

[8] I. Ghozali, "Structural Equation Modelling : Teori, Konsep, Aplikasi Dengan Program LISREL 9.54", BP Undip, Semarang, 2005

[9] Juniarti, "Good Corporate Governance and Predicting Financial Distress Using Logistic and Probit Regression Model", Vol. 15, No. 1, pp. 43-50, 2013, https://doi.org/10.9744/jak.15.1.43-50

[10] K. N. Maholtra, "Marketing Reseach : An Applied Orientation Sixth Ed Pearson Education (Sixth Edition)", Pearson Education, 2010

[11] L. E. Muliani, G. A. Yuniarta, K. Sinarwati, "Pengaruh Kinerja Keuangan Terhadap Nilai Perusahaan Dengan Pengungkapan Corporate Social Responcibility \& Good Corporate Governance Sebagai Variabel Pemoderasi (Studi Kasus Di Bursa Efek Indonesia Periode 2010-2012)", eJournal Akuntansi, Universitas Pendidikan Ganesha, 2014

[12] LPPI, "Implementasi Good Corporate Governance (GCG) Industri Perbankan Nasional Tahun 2007 s.d. 2017”, Lembaga Pengembangan Perbankan Indonesia, Jakarta, 2018

[13] M. A. Hitt, R. Ireland, D. Hoskisson, "Manajemen Strategis, Konsep Daya Saing Dan Globalisasi”, Salemba Empat, Jakarta, 2004

[14] M. A. Tertius, Y. J. Christiawan, "Pengaruh Good Corporate Governance terhadap Kinerja Perusahaan pada Sektor Keuangan", Business Accounting Review, Vol. 3, No. 1, pp. 223-232, 2015

[15] M. Baird, "The Proper Governance of Companies Will Become as Crucial to the World Economy as the Proper Governing of Countries", 2000, Paper

[16] M. D. A. Pella, U. Sumarwan, A. Daryanto, Kirbrandoko, "Model Implementasi Strategi Sebagai Determinan Kinerja Perusahaan",
Jurnal Manajemen Teknologi, Vol. 12, No. 1, Institut Pertanian Bogor, 2013

[17] M. D. Hadad, "Peraturan Otoritas Jasa Keuangan Nomor 55/POJK.03/2016 tanggal 07 Desember 2016 tentang Penerapan Tata Kelola Bagi Bank Umum”, Jakarta, 2016

[18] M. E. Civelek, M. Çemberci, O. K. Artar, N. Uca, "Key Factors of Sustainable Firm Performance : A Strategic Approach”, 2015

[19] M. E. Porter, "Competitive Strategy”, Free Press, New York, 1985

[20] M. Simarro, D. Devece, C. and L. Albert, "How Information Systems Strategy Moderates the Relationship Between Business Strategy and Performance", Journal of Business Research, Vol. 68, No. 7, pp. 15921594, 2015, https://doi.org/10.1016/j.jbusres.2015.01.057

[21] OJK (Otoritas Jasa Keuangan), "Laporan Publikasi Bank Umum Konvensional", 2018, Diakses pada tanggal 18 Juni 2018, https://www.ojk.go.id/id/kanal/perbankan/data-dan-statistik/laporankeuangan-perbankan/default.aspx

[22] P. Bayu Aji, "Analisis Tingkat Kesehatan Bank Berdasarkan Metode CAMELS dan Metode RGEC", Jurnal Akuntansi, Universitas Negeri Surabaya, 2012

[23] R. E. Schumacker, R. G. Lomax, R. G, “A Beginner's Guide to Structural Equation Modeling", Second Edition, Lawrance Erlbaum Associates, Inc. Pub, New Jersey, 2004

[24] R. J. Harrington, K. W. Kendall, "Strategy Implementation Success: The Moderating Effects of Size and Environmental Complexity and the Mediating Effects of Involvement", Journal of Hospitality \& Tourism Research, 2006

[25] Ripley and Franklin, "Policy Implementation and Bureaucracy", Dorsey Press, Chicago, 1982

[26] S. Sarafina, M. Saifi, "Pengaruh Good Corporate Governance Terhadap Kinerja Keuangan \& Nilai Perusahaan”, Jurnal Administrasi Bisnis Vol. 50 No. 3, Universitas Brawijaya, Malang, 2017

[27] S. Y. Lin and A. C. Hsui, "Correlation Between Office Locations, Corporate Governance and Business Performance", International Journal of Economics and Financial Issues, Vol. 7, No. 4, pp. 668-676, 2017

[28] Solimun, "Multivariate Analysis Structural Equation Modelling (SEM) Menggunakan Lisrel \& Amos", Fakultas MIPA, 2005

[29] Sugiyono, "Metode Penelitian Kuantitatif, Kualitatif dan Kombinasi (Mixed Methods)", Alfabeta, Bandung, 2013

[30] T. L. Wheelen, D. J. Hunger, "Strategic Management \& Business Policy", Pearson International Edition, New Jersey, 2018

[31] W. Adipoetra, "Upaya Peningkatan Kinerja Pemasaran Dengan Konsep Marketing Strategy Making Process Melalui Kreatifitas Strategi Dan Pembelajaran Organisasional", Tesis, Magister Manajemen Program Pascasarjana, Universitas Diponegoro, Semarang, 2004

[32] W. DeSarbo, C. A. D. Benedetto, M. Song, and I. Sinha, "Revisiting the Miles and Snow Strategic Framework: Uncovering Interrelationships between Strategic Types, Capabilities, Environmental Uncertainty, and Firm Performance", Strategic Management Journal, Vol. 26, pp. 47-74, 2005

[33] Z. Wahyudi, "Manajemen Risiko Bank Islam", Salemba Empat, Jakarta, 2013

[34] N. A. Hamdani, T. Susanto, and G. Abdul Fatah Maulani, "Framework of Architectural Marketing Capabilities in Regional Development Bank," Int. J. Eng. Technol., vol. 7, no. 3.25, pp. 166-169, 2018.

[35] N. A. Hamdani, "Contributing Factors of Good Corporate Governance and Employee Performance to Bank Performance," J. Soc. Sci. Res., no. SPI4, pp. 235-237, 2019.

[36] N. A. Hamdani and G. A. F. Maulani, "Analysis of Marketing of Sharia Banking Service Products Based on Consumer Perception," no. January 2017, pp. 515-520, 2018. 